\title{
Sole-Source LED Lighting and Fertility Impact Shoot and Root Tissue Mineral Elements in Chinese Kale (Brassica oleracea var. alboglabra)
}

\author{
T. Casey Barickman ${ }^{1}$, Dean A. Kopsell ${ }^{* 2}$, Carl E. Sams ${ }^{3}$, and Robert C. Morrow ${ }^{4}$ \\ 1 Mississippi State University, North Mississippi Research and Extension Center, Verona, MS 38879, United \\ States \\ 2 Department of Environmental Horticulture, University of Florida, Gainesville, FL 32611, United States. \\ 3 The University of Tennessee, Department of Plant Sciences, Knoxville, TN 37996, United States \\ 4 Orbital Technologies Corporation, Madison, WI 53717, United States \\ * Correspondence: dean.kopsell@ufl.edu; Tel.: (352) 294-3059, Department of Environmental Horticulture, \\ University of Florida, Gainesville, FL 32611, United States
}

\begin{abstract}
The current study investigated the impacts of light quality and different levels of fertility on mineral nutrient concentrations in shoot and root tissues of Chinese kale (Brassica oleracea var. alboglabra). 'Green Lance' Chinese kale were grown under: 1) fluorescent/incandescent light; 2) $10 \%$ blue $(447 \pm 5 \mathrm{~nm}) / 90 \%$ red $(627 \pm 5 \mathrm{~nm}$ ) LED light; 3$) 20 \%$ blue / 80\% red LED light; and 4 ) $40 \%$ blue / $60 \%$ red LED light as sole-source lighting at two different levels of fertility. All plants were harvested $30 \mathrm{~d}$ after seeding, and shoot and root tissues were analyzed for mineral nutrients. Lighting and fertility interacted to influence kale shoot and root mineral nutrient concentrations. Results indicate sole-source LED lighting used in production can impact mineral nutritional values of baby leafy greens now popular for the packaged market.
\end{abstract}

Keywords: blue light; calcium, iron; magnesium; potassium; red light

\section{Introduction}

The Inorganic elements participate in many different mechanisms in plant photosynthesis. Some elements participate in the structure of the photosynthetic apparatus, while others play vital roles in translocation of photosynthetic products and sink tissue formation (fruits, grains and storage organ). ${ }^{1}$ Elements can be considered to have direct effects on photosynthesis when deficiencies of a particular element cause a rapid decline in photosynthetic activity. Direct effects of elemental deficiencies are usually considered reversible as reintroduction at a proper level results in resumption of photosynthetic activity. Indirect effects are not usually readily reversible. They occur over a longer period of time and involve elements not necessarily critical in the photosynthetic process, but instead are crucial in the production of metabolites or organs that are directly involved in photosynthesis. Chlorophyll loss and necrosis that accompany an elemental deficiency result in reduced leaf area and metabolic activity. Often, by the time symptoms are visible, chloroplast alteration is severe. The symptoms of many elemental deficiencies are simply the visual manifestations of decreased photosynthetic activity by a plant ${ }^{2}$ which have impacts on light utilization.

Only a small percentage of solar spectral irradiance is captured by chlorophyll $a$ and used in photosynthesis. Maximum light absorption by chlorophyll pigments and quantum yield of photosynthesis occur primarily in the blue and red regions of the visible light spectrum. ${ }^{3}$ Light-harvesting complexes composed of accessory pigments (chlorophyll $b$, lutein, and $\beta$-carotene) 
improve light harvesting efficiency in the photosynthetically active radiation (PAR) spectrum and direct the flow of excitation energy to the reaction centers. ${ }^{4}$ However, absorption of excess light energy has the potential to damage photosynthetic machinery, and accessory pigments also play an important role in photoprotection. ${ }^{5}$ Damage to the photosynthetic apparatus by light intensity or quality (such as high ultraviolet light) will impact the product of metabolites and ATP used to drive elemental ion uptake and flux.

Light influences concentrations of plant elements by impacting the amount of carbohydrates produced and enzymatic activities within primary metabolic pathways. ${ }^{6}$ Absorption of PAR by photosystems I and II (PSI and PSII) result in $\mathrm{H}^{+}$ions fluxes within the thylakoid which need to be counter balanced by fluxes of other cations. The generation of ATP in the light reactions of photosynthesis become a source of energy for active ion movements. ${ }^{7}$ Translocated carbohydrates are required for root respiration, which provides the energy needed for active uptake mechanisms. ${ }^{8}$ Recent research demonstrates that shoot tissue elemental concentrations can be impacted by both light quality and light intensity. Specialized photoreceptors in plants called phototropins change metabolic homeostasis and mobilize $\mathrm{Ca}^{2+}$ in response to blue light. ${ }^{9}$ Kopsell et al. demonstrated that blue/red LED lighting ratios in a sole-source light environment acted to increase sprouting broccoli (Brassica oleracea var italica) microgreen (21-d old) shoot tissue concentrations $[\mathrm{mg} / \mathrm{g}$ dry mass $(\mathrm{DM})]$ of calcium $(\mathrm{Ca})$, potassium $(\mathrm{K})$, magnesium $(\mathrm{Mg})$, phosphorus $(\mathrm{P})$, sulfur $(\mathrm{S})$, boron $(\mathrm{B})$, iron $(\mathrm{Fe})$, manganese $(\mathrm{Mn})$, molybdenum $(\mathrm{Mo})$, and zinc $(\mathrm{Zn})$ as compared to broad spectrum incandescent/fluorescent lighting. ${ }^{10}$ Changing the light quality environment from blue/red light to only blue, and concomitantly reducing the light intensity from $350 \mu \mathrm{mols} / \mathrm{m}^{2} / \mathrm{sec}$ (blue/red LED) to $41 \mu \mathrm{mols} / \mathrm{m}^{2} / \mathrm{sec}$ (blue LED), for 5 days pre-harvest acted to significantly increase macro-element and micro-element concentrations in sprouting broccoli microgreens. ${ }^{11}$ Increasing the photosynthetic photon flux density (PPFD) from 200 to $400 \mu \mathrm{mols} / \mathrm{m}^{2} / \mathrm{sec}$ resulted in increased concentrations ( $\mu$ g/plant) of $\mathrm{B}$, copper $(\mathrm{Cu}), \mathrm{Fe}, \mathrm{Mn}$, and $\mathrm{Zn}$ in a variety of tropical legume cover crops. ${ }^{12}$

Our hypothesis is that accumulation of mineral elements in the shoot and root tissues of 30-day old (baby) leafy specialty vegetable crops will be higher under narrow-band LED light as compared to full spectrum fluorescent/incandescent light in controlled environments. Because of the increases in shoot tissue mineral elements of 21-day old sprouting broccoli microgreens grown under LED lighting in previous studies, ${ }^{10,11}$ the objective of this study was to measure the impact of different ratios of blue/red LED light on shoot and root tissue mineral elements in baby Chinese kale (B. oleracea var. alboglabra). A comparison among different blue/red LED ratio light treatments was also made with traditional fluorescent/incandescent in controlled environments. Plants were grown under $1 / 4$ or $1 / 2$ strength Hoagland's nutrient solutions ${ }^{13}$ to establish any possible light by fertility experimental interactions.

\section{Results}

The acquisition of mineral nutrients into Chinese kale shoot tissue demonstrated a significant interaction when plants were grown under four light quality treatments within two fertility regimes. Micronutrients, $\mathrm{Ca}, \mathrm{K}, \mathrm{Mg}$, $\mathrm{P}$, and $\mathrm{S}$ (Table 1) were all affected by the interaction and in general had the highest concentrations in shoot tissue under the $1 / 2$ strength fertility paired with the $20 \%$ blue/80\% red LED light treatment. Interestingly, kale plants grown under the $1 / 4$ strength fertility paired with the $10 \%$ blue $/ 90 \%$ red LED light treatments were significantly similar. For example, there was a less than $10 \%$ difference between $1 / 2$ strength fertility paired with the $20 \%$ blue $/ 80 \%$ red LED and $1 / 4$ strength fertility treatment combination for $\mathrm{Ca}, \mathrm{Mg}, \mathrm{P}$, and S (Table 1). Conversely, the combination of fluorescent/incandescent light treatments with $1 / 4$ strength fertilizer were among the lowest mineral nutrients in kale shoot tissue. For example, K concentrations in shoot tissue under the $20 \%$ blue/ $80 \%$ red LED and $1 / 2$ strength fertility treatments were $68.1 \%$ higher than in the fluorescent/incandescent light combined with the $1 / 4$ strength fertilizer treatment (Table 1). The K concentrations in shoot tissue under $20 \%$ blue $/ 80 \%$ red LED and $1 / 2$ strength fertility treatments were 
also $50.4 \%$ higher compared to the fluorescent/incandescent light combined with the $1 / 4$ strength fertilizer treatment (Table 1). The micronutrients of $\mathrm{Mn}$ and Mo also had significant interactions between light and fertility treatments (Table 1). In general, there were significant increases in $\mathrm{Mn}$ and Mo when comparing LED lights and $1 / 2$ strength fertility treatments and LED lights and $1 / 4$ strength fertility and fluorescent/incandescent light combined with fertility. The lowest concentrations in kale shoot $\mathrm{Mn}$ and Mo occurred under the fluorescent/incandescent light combined with the $1 / 4$ strength fertilizer treatment (Table 1). There were $42.4 \%$ and $57.8 \%$ decreases in Mo and Mn concentrations, respectively, when comparing the two treatment combinations (Table 1). However, there were not significant changes from the LED lights and $1 / 2$ strength fertility treatments and the $1 / 4$ strength fertility paired with the $10 \%$ blue/90\% red LED light treatments (Table 1). Consequently, there were not significant changes in $\mathrm{B}$ and $\mathrm{Cu}$ in kale shoot tissue treated with differences in light and fertility treatments (Table 1).

There were limited interactions between light and fertility treatments when determining the mineral nutrient concentrations in the root tissue. For instance, there were only significant interactions for Mo and $\mathrm{K}$ that exhibited similar trends with differences between LED lights and $1 / 2$ strength fertility treatments and LED lights and $1 / 4$ strength fertility and fluorescent/incandescent light combined with fertility (Table 2). The combination of these treatments demonstrated a 42.7 and a $75.0 \%$ difference between concentration in the root tissue for Mo and $\mathrm{K}$, respectively. On the other hand, $\mathrm{Mg}$ concentrations in kale root tissue demonstrate opposing results that indicated increases under LED lights combined with $1 / 4$ strength fertility and fluorescent/incandescent light combined with fertility (Table 2). For instance, concentrations of $\mathrm{Mg}$ were similar in the fluorescent/incandescent lights under either fertility treatment or LED lights combined with $1 / 4$ strength fertility. The least amount of $\mathrm{Mg}$ in kale root tissue occurred in the $40 \%$ blue/ $60 \%$ red LED light combined with $1 / 2$ strength fertility (Table 2).

Light quality had a significant effect on kale shoot Fe and Zn concentrations (Table 3). In all instances, kale plants grown under LED light accumulated higher concentrations of Fe and $\mathrm{Zn}$ compared to the fluorescent/incandescent light treatments. The Fe concentrations were greatest in the $40 \%$ blue $/ 60 \%$ red LED light treatments and increased by $34.9 \%$ over the fluorescent/incandescent light treatments (Table 3). The Zn concentrations were greatest under the $10 \%$ blue $/ 90 \%$ red LED light ratio and increased by $42.1 \%$ compared to the fluorescent/incandescent light treatments (Table 3). Conversely, kale plant root concentrations of S, B, and Zn were significantly increased under the $10 \%$ blue/ $90 \%$ red LED light ratio treatment (Table 4). Kale plants demonstrated superior accumulation of $\mathrm{S}, \mathrm{B}$, and $\mathrm{Zn}$ in the root tissue under the $10 \%$ blue $/ 90 \%$ red LED light ratio with increases of $34.0 \%, 39.3 \%$, and $55.1 \%$, respectively, compared to the fluorescent/incandescent light treatments (Table 4).

Fertility treatments of $1 / 4$ and $1 / 2$ strength fertilizer significantly impacted the concentrations of $\mathrm{P}, \mathrm{Mn}, \mathrm{Fe}$, and $\mathrm{Zn}$ in kale root tissue (Table 5). In all instances, $1 / 2$ strength fertilizer increased the amount of these minerals in the root tissue compared to the $1 / 4$ strength fertilizer. Root tissue $\mathrm{P}, \mathrm{Mn}$, $\mathrm{Fe}$, and $\mathrm{Zn}$ concentrations increased by $16.0 \%, 51.4 \%, 40.4 \%$, and $20.5 \%$, respectively (Table 5 ). 
Table 1. The Effects of Four Light Quality and Two Fertility Treatments on Shoot Tissue Mineral Element Concentrations for 'Green Lance' Chinese Kale (Brassica oleracea var alboglabra) Grown in Controlled Environments ${ }^{a}$.

\begin{tabular}{|c|c|c|c|c|c|c|c|c|c|c|c|}
\hline & $\mathrm{Ca}$ & $\mathrm{K}$ & $\mathrm{Mg}$ & $\mathrm{P}$ & $S$ & B & $\mathrm{Cu}$ & $\mathrm{Fe}$ & $\mathrm{Mn}$ & Mo & $\mathrm{Zn}$ \\
\hline Light Quality $^{\mathrm{b}}$ & \multicolumn{5}{|c|}{$\mathrm{mg} / \mathrm{g}$ dry mass $\mathrm{s}^{\mathrm{c}}$} & \multicolumn{6}{|c|}{$\mu \mathrm{g} / \mathrm{g}$ dry mass ${ }^{\mathrm{c}}$} \\
\hline & \multicolumn{11}{|c|}{$1 / 4$ Strength Fertility ${ }^{d}$} \\
\hline Fluorescent/Incandescent & $15.01 \mathrm{c}$ & $13.32 \mathrm{e}$ & $2.70 \mathrm{e}$ & $4.03 \mathrm{~d}$ & $4.56 \mathrm{~d}$ & $53.11 \mathrm{bc}$ & $2.56 \mathrm{a}$ & $33.03 \mathrm{c}$ & $57.74 \mathrm{~b}$ & $1.29 \mathrm{~d}$ & $17.70 \mathrm{~b}$ \\
\hline 10\% Blue/90\% Red LED & $22.46 \mathrm{a}$ & $34.36 \mathrm{bc}$ & $4.04 \mathrm{ab}$ & $6.73 \mathrm{abc}$ & $9.48 \mathrm{a}$ & $51.89 \mathrm{bc}$ & $3.22 \mathrm{a}$ & 51.39 a & 110.78 a & $2.36 \mathrm{a}$ & $31.61 \mathrm{a}$ \\
\hline 20\% Blue/80\% Red LED & $18.79 \mathrm{~b}$ & $23.28 \mathrm{~d}$ & $3.37 \mathrm{~cd}$ & $5.92 \mathrm{c}$ & $6.59 \mathrm{c}$ & $51.93 \mathrm{bc}$ & $2.93 \mathrm{a}$ & $42.51 \mathrm{abc}$ & $71.50 \mathrm{~b}$ & $1.68 \mathrm{~cd}$ & $28.41 \mathrm{a}$ \\
\hline \multirow[t]{2}{*}{ 40\% Blue/60\% Red LED } & $20.87 \mathrm{ab}$ & $30.12 \mathrm{c}$ & $3.95 \mathrm{ab}$ & $7.03 \mathrm{ab}$ & $7.92 \mathrm{~b}$ & $56.22 \mathrm{ab}$ & $3.36 \mathrm{a}$ & $50.29 \mathrm{a}$ & $76.65 \mathrm{~b}$ & $2.07 \mathrm{abc}$ & $26.95 \mathrm{a}$ \\
\hline & \multicolumn{11}{|c|}{$1 / 2$ Strength Fertility ${ }^{\mathrm{d}}$} \\
\hline Fluorescent/Incandescent & $15.05 \mathrm{c}$ & $20.72 \mathrm{~d}$ & $2.90 \mathrm{de}$ & $4.43 \mathrm{~d}$ & $5.62 \mathrm{~cd}$ & $51.27 \mathrm{bc}$ & $2.93 \mathrm{a}$ & $33.56 \mathrm{bc}$ & $74.61 \mathrm{~b}$ & $1.56 \mathrm{~cd}$ & $18.86 \mathrm{~b}$ \\
\hline 10\% Blue/90\% Red LED & $18.84 \mathrm{~b}$ & $36.80 \mathrm{ab}$ & $3.60 \mathrm{bc}$ & $6.43 \mathrm{bc}$ & $8.70 \mathrm{ab}$ & $50.31 \mathrm{c}$ & $3.34 \mathrm{a}$ & $46.50 \mathrm{ab}$ & $117.94 \mathrm{a}$ & $1.78 \mathrm{bcd}$ & $31.52 \mathrm{a}$ \\
\hline 20\% Blue/80\% Red LED & $22.78 \mathrm{a}$ & $41.74 \mathrm{a}$ & $4.45 \mathrm{a}$ & $7.43 \mathrm{a}$ & $9.12 \mathrm{ab}$ & $58.73 \mathrm{a}$ & $3.08 \mathrm{a}$ & 54.85 a & 136.66 a & $2.24 \mathrm{ab}$ & $30.20 \mathrm{a}$ \\
\hline 40\% Blue/60\% Red LED & $22.03 \mathrm{a}$ & $39.01 \mathrm{ab}$ & $4.19 \mathrm{a}$ & $6.89 \mathrm{ab}$ & $9.00 \mathrm{ab}$ & $53.54 \mathrm{abc}$ & $3.11 \mathrm{a}$ & $51.98 \mathrm{a}$ & 119.77 & $1.97 \mathrm{abc}$ & $32.17 \mathrm{a}$ \\
\hline $\mathrm{SE}_{\alpha=0.05}$ & 1.17 & 2.42 & 0.26 & 0.50 & 0.48 & 2.32 & 0.32 & 5.53 & 10.69 & 0.19 & 2.28 \\
\hline \multicolumn{12}{|l|}{ Source of variation ${ }^{\mathrm{e}}$} \\
\hline Light & $* * *$ & $* * *$ & $* * *$ & $* * *$ & $* * *$ & $\mathrm{~ns}$ & $\mathrm{~ns}$ & $* *$ & $* * *$ & $* *$ & $* * *$ \\
\hline Fertility & ns & $* * *$ & $\mathrm{~ns}$ & $\mathrm{~ns}$ & $* *$ & $\mathrm{~ns}$ & $\mathrm{~ns}$ & $\mathrm{~ns}$ & $* * *$ & $\mathrm{~ns}$ & $\mathrm{~ns}$ \\
\hline Light $x$ Fertility & $* *$ & $* *$ & $* *$ & $*$ & $* *$ & $\mathrm{~ns}$ & ns & ns & $*$ & $*$ & $\mathrm{~ns}$ \\
\hline
\end{tabular}

${ }^{a}$ Mean values represent 6 total plants per treatment for 2 replications of each of 3 experimental repeats. ${ }^{\mathrm{b}}$ All light treatments at an intensity of $250 \pm 10 \mu \mathrm{mol} / \mathrm{m}^{2} / \mathrm{sec}$; percentages indicate contributions to total light intensity (see text for light treatment details). ${ }^{\mathrm{c}}$ Means followed by the same letter are not statistically different, $\alpha=0.05$. $\mathrm{d} 1 / 4$ and $1 / 2$ Strength Fertility describe concentrations based on Hoagland's \#2 nutrient solution (see text for nutrient concentration details). ${ }^{e}$ Individual effects and interactions are given according to ANOVA tests, with significance as: $* \mathrm{P} \leq 0.05 ; * * \mathrm{P} \leq 0.01 ; * * * \mathrm{P} \leq 0.001$; ns, not significant. 
Table 2. The Effects of Four Light Quality and Two Fertility Treatments on Root Tissue Mineral Element Concentrations for 'Green Lance' Chinese Kale (Brassica oleracea var alboglabra) Grown in Controlled Environmentsa.

\begin{tabular}{|c|c|c|c|c|c|c|c|c|c|c|c|}
\hline & $\mathrm{Ca}$ & K & $\mathrm{Mg}$ & $\mathrm{P}$ & S & B & $\mathrm{Cu}$ & $\mathrm{Fe}$ & Mn & Mo & $\mathrm{Zn}$ \\
\hline Light Quality ${ }^{b}$ & \multicolumn{5}{|c|}{$\mathrm{mg} / \mathrm{g}$ dry mass ${ }^{c}$} & \multicolumn{6}{|c|}{$\mu g / g$ dry mass ${ }^{c}$} \\
\hline & \multicolumn{11}{|c|}{ 1/4 Strength Fertility ${ }^{\mathrm{d}}$} \\
\hline \multirow{2}{*}{$\begin{array}{l}\text { Fluorescent/Incandescent } \\
\text { 10\% Blue/90\% Red LED }\end{array}$} & $4.62 \mathrm{a}$ & $10.86 \mathrm{c}$ & $5.01 \mathrm{abc}$ & $3.85 \mathrm{~b}$ & $5.30 \mathrm{~b}$ & $41.67 \mathrm{~b}$ & 15.77 a & $101.23 \mathrm{bc}$ & $202.24 b$ & $1.10 \mathrm{~d}$ & $32.52 \mathrm{~d}$ \\
\hline & $4.75 \mathrm{a}$ & $30.31 \mathrm{ab}$ & $4.59 \mathrm{bc}$ & $5.78 \mathrm{a}$ & $\begin{array}{c}11.02 \\
\mathrm{a}\end{array}$ & $70.61 \mathrm{a}$ & $18.50 \mathrm{a}$ & $93.24 \mathrm{c}$ & $487.78 \mathrm{ab}$ & $2.05 \mathrm{a}$ & $70.43 \mathrm{ab}$ \\
\hline 20\% Blue/80\% Red LED & $5.00 \mathrm{a}$ & $18.58 \mathrm{bc}$ & $5.37 \mathrm{ab}$ & $\begin{array}{c}5.18 \\
\mathrm{ab}\end{array}$ & $6.14 b$ & $39.06 \mathrm{~b}$ & $17.49 \mathrm{a}$ & $75.94 \mathrm{c}$ & $274.91 \mathrm{~b}$ & $1.36 \mathrm{~cd}$ & $42.28 \mathrm{~cd}$ \\
\hline 40\% Blue/60\% Red LED & $5.16 \mathrm{a}$ & $16.11 \mathrm{c}$ & $6.37 \mathrm{a}$ & $5.84 \mathrm{a}$ & $5.32 \mathrm{~b}$ & $37.29 \mathrm{~b}$ & $13.06 \mathrm{a}$ & 86.52 c & 290.36 b & $1.55 \mathrm{abcd}$ & $35.86 \mathrm{~d}$ \\
\hline & \multicolumn{11}{|c|}{$1 / 2$ Strength Fertility ${ }^{d}$} \\
\hline \multirow{2}{*}{$\begin{array}{l}\text { Fluorescent/Incandescent } \\
\text { 10\% Blue/90\% Red LED }\end{array}$} & $4.94 \mathrm{a}$ & $13.73 \mathrm{c}$ & $5.41 \mathrm{ab}$ & $6.67 \mathrm{a}$ & $6.08 \mathrm{~b}$ & $32.96 \mathrm{~b}$ & $18.08 \mathrm{a}$ & $152.69 \mathrm{a}$ & $483.31 \mathrm{ab}$ & $1.39 \mathrm{~cd}$ & $37.74 \mathrm{~d}$ \\
\hline & $3.79 \mathrm{a}$ & $37.80 \mathrm{a}$ & $4.44 \mathrm{~d}$ & $6.01 \mathrm{a}$ & $\begin{array}{c}9.24 \\
\mathrm{ab}\end{array}$ & $52.10 \mathrm{ab}$ & $14.71 \mathrm{a}$ & 150.84 a & 704.97 a & $1.49 \mathrm{bcd}$ & $77.23 \mathrm{a}$ \\
\hline 20\% Blue/80\% Red LED & $4.72 \mathrm{a}$ & $40.06 \mathrm{a}$ & $3.70 \mathrm{~cd}$ & $6.53 \mathrm{a}$ & $\begin{array}{c}8.18 \\
a b\end{array}$ & $45.68 \mathrm{~b}$ & $13.40 \mathrm{a}$ & $159.90 \mathrm{a}$ & $719.74 \mathrm{a}$ & $1.92 \mathrm{ab}$ & $50.12 \mathrm{bcd}$ \\
\hline 40\% Blue/60\% Red LED & $4.37 \mathrm{a}$ & $43.46 \mathrm{a}$ & $3.43 \mathrm{~cd}$ & $6.37 \mathrm{a}$ & $\begin{array}{c}8.58 \\
a b\end{array}$ & $47.01 \mathrm{~b}$ & $13.25 \mathrm{a}$ & $135.00 \mathrm{ab}$ & $677.21 \mathrm{a}$ & $1.77 \mathrm{abc}$ & $62.79 \mathrm{abc}$ \\
\hline $\mathrm{SE}_{\alpha=0.05}$ & 0.89 & 4.34 & 0.86 & 0.68 & 1.44 & 10.47 & 3.10 & 24.10 & 104.00 & 0.22 & 8.98 \\
\hline \multicolumn{12}{|l|}{ Source of variatione } \\
\hline Light & ns & $* * *$ & * & ns & $*$ & * & ns & ns & ns & $*$ & $* *$ \\
\hline Fertility & ns & $* * *$ & $* * *$ & * & ns & ns & ns & $* * *$ & $* * *$ & ns & $*$ \\
\hline Light $x$ Fertility & ns & * & * & ns & ns & ns & ns & ns & ns & * & ns \\
\hline \multicolumn{12}{|c|}{$\begin{array}{l}\text { aMean values represent } 6 \text { total plants per treatment for } 2 \text { replications of each of } 3 \text { experimental repeats. }{ }^{b} \text { All light treatments at an intensity of } 250 \pm 10 \\
\mu \mathrm{mol} / \mathrm{m}^{2} / \mathrm{sec} \text {; percentages indicate contributions to total light intensity (see text for light treatment details). }{ }^{\mathrm{c}} \text { Means followed by the same letter are not } \\
\text { statistically different, } \alpha=0.05 . \mathrm{d} 1 / 4 \text { and } 1 / 2 \text { Strength Fertility describe concentrations based on Hoagland's } \# 2 \text { nutrient solution (see text for nutrient } \\
\text { concentration details). eIndividual effects and interactions are given according to ANOVA tests, with significance as: }{ }^{*} \mathrm{P} \leq 0.05 ;{ }^{* *} \mathrm{P} \leq 0.01 ;{ }^{* * *} \mathrm{P} \leq 0.001 \text {; } \\
\text { ns, not significant. }\end{array}$} \\
\hline
\end{tabular}


Table 3. The Main Effects of Light Quality Treatment on Shoot Tissue Mineral Element Concentrations for 'Green Lance' Chinese Kale (Brassica oleracea var alboglabra) Grown in Controlled Environments ${ }^{a}$.

$\mathrm{Fe}$

Light Quality ${ }^{b}$

Fluorescent/Incandescent

10\% Blue $/ 90 \%$ Red LED

$20 \%$ Blue $/ 80 \%$ Red LED

$40 \%$ Blue/60\% Red LED

$P$-Value

$\mathrm{SE} \alpha=0.05$

$33.29 \mathrm{~b}$

$\mu \mathrm{g} / \mathrm{g}$ dry mass ${ }^{c}$

$\mathrm{Zn}$

${ }^{a}$ Mean values represent 6 total plants per treatment for 2 replications of each of 3 experimental repeats. ${ }^{b}$ All light treatments at an intensity of $250 \pm 10 \mu \mathrm{mol} / \mathrm{m}^{2} / \mathrm{sec}$; percentages indicate contributions to total light intensity (see text for light treatment details). 'Means followed by the same letter are not statistically different, $\alpha=0.05$. ${ }^{d}$ Individual effects and interactions are given according to ANOVA tests, with significance as: ${ }^{* *} P \leq 0.01 ;{ }^{* *} P \leq 0.001$.

Table 4. The Main Effects of Light Quality Treatments on Root Tissue Mineral Element Concentrations for 'Green Lance' Chinese Kale (Brassica oleracea var alboglabra) Grown in Controlled Environments ${ }^{a}$.

\section{S}

Light Quality ${ }^{b}$

Fluorescent/Incandescent

10\% Blue/90\% Red LED

20\% Blue/80\% Red LED

$40 \%$ Blue/60\% Red LED

$P$-Value

$\mathrm{SE}_{\alpha=0.05}$ mg/g dry mass ${ }^{c}$

$6.69 \mathrm{~b}$

10.13 a

$7.16 \mathrm{~b}$

$6.95 \mathrm{~b}$

1.08

\section{B}

$\mu \mathrm{g} / \mathrm{g}$ dry mass ${ }^{c}$
$35.13 \mathrm{~b}$

73.83 a

$46.20 \mathrm{~b}$

$49.33 \mathrm{~b}$

$42.15 \mathrm{~b}$

9.04
Zn

**

7.17

${ }^{a}$ Mean values represent 6 total plants per treatment for 2 replications of each of 3 experimental repeats. ${ }^{b}$ All light treatments at an intensity of $250 \pm 10 \mu \mathrm{mol} / \mathrm{m}^{2} / \mathrm{sec}$; percentages indicate contributions to total light intensity (see text for light treatment details). ${ }^{c}$ Means followed by the same letter are not statistically different, $\alpha=0.05 .{ }^{d}$ Individual effects and interactions are given according to ANOVA tests, with significance as: ${ }^{*} P \leq 0.05 ;{ }^{* *} P \leq 0.01$. 
Table 5. The Main Effects of Fertility Treatments on Root Tissue Mineral Element Concentrations for 'Green Lance' Chinese Kale (Brassica oleracea var alboglabra) Grown in Controlled Environments ${ }^{a}$.

$\mathbf{P}$

\section{Fertility}

$1 / 4$ Strength Fertility

1/2 Strength Fertility ${ }^{c}$

$P$-Value ${ }^{\mathrm{d}}$

$\mathrm{SE} \alpha=0.05$ mg/g dry mass ${ }^{b}$

$5.16 \mathrm{~b}$
$6.14 \mathrm{a}$
$*$
0.5

Mn

Fe

$\mu \mathrm{g} / \mathrm{g}$ dry mass ${ }^{\mathrm{b}}$

313.82 b

646.31 a

$* * *$

52
89.23 b

149.61 a

***

21.87
Zn

45.27 b

56.97 a

6.06

${ }^{a}$ Mean values represent 6 total plants per treatment for 2 replications of each of 3 experimental repeats. ${ }^{b}$ Means followed by the same letter are not statistically different, $\alpha=0.05 .{ }^{c 1 / 4}$ and $1 / 2$ Strength Fertility describe concentrations based on Hoagland's \#2 nutrient solution (see text for nutrient concentration details). ${ }^{d}$ Individual effects and interactions are given according to ANOVA tests, with significance as: ${ }^{*} P \leq 0.05$; ${ }^{* * *} P \leq 0.001$. 


\section{Discussion}

Responses in kale biomass from the current study have been published previously. ${ }^{15}$ Kale shoot fresh mass (FM) was influenced by light treatment, fertility treatment, and their interaction. Kale shoot tissue FM under $1 / 4$ strength fertility was 17.30, 9.24, 11.03, and $9.11 \mathrm{~g}$ per plant for the light quality treatments of fluorescent/incandescent light, 10\% blue / $90 \%$ red, $20 \%$ blue / $80 \%$ red, and $40 \%$ blue / $60 \%$ red, respectively. Kale shoot tissue FM under $1 / 2$ strength fertility was 25.74 , 9.27, 13.92, and $11.63 \mathrm{~g}$ per plant for the light quality treatments of fluorescent/incandescent light, $10 \%$ blue / $90 \%$ red, $20 \%$ blue / $80 \%$ red, and $40 \%$ blue / $60 \%$ red, respectively. ${ }^{15}$

Previous LED research on leafy greens has focused on growth, morphological changes, yield, and phytonutrient concentrations. For example, Chen et al. indicated that there were significant differences in plant height, width, FM, DM, and leaf length and leaf width in lettuce grown under red and blue LED light at different daily light integrals. ${ }^{16}$ In another study, hypocotyl length, leaf area, FM, and DM were significantly affected by LED photosynthetic photon flux density (PPFD) in Brassica microgreens. ${ }^{17}$ Previous research has indicated that the addition of blue LED light increased production of phenolic acids in basil (Ocimum basilicum) and flavonoids in arugula (Eruca vesicaria). ${ }^{18} \quad$ Kopsell et al. demonstrated that interactions of light quality, comparing fluorescent/incandescent and LED lights, and fertility significantly increased Chinese kale shoot biomass and pigment concentrations. ${ }^{15}$ Yan et al. demonstrated similar results comparing fluorescent/incandescent and LED lights with biomass accumulation but also discovered significant differences in vitamin C and soluble protein content in lettuce (Lactuca sativa). ${ }^{19}$

Limited research exists on how different LED light ratios affect the mineral nutrient concentrations and accumulation. Previous research on LEDs and mineral nutrients have focused on reduction of nitrate in the leaf and shoot tissues of hydroponically grown leafy greens, since the accumulation and concentrations are elevated in these growth systems. For example, a reduction of nitrate concentrations in lettuce leaf tissue was observed when plants were treated with red LED light. ${ }^{20,21}$ Previous research has also indicated that green LED light reduces nitrate concentrations in hydroponically grown lettuce.22 However, there is a lack of knowledge of how LED light ratios coupled with differing concentrations of a hydroponic nutrient solution affect mineral nutrient concentrations and accumulation in shoot and root tissues.

Even though there is limited research information on different nutrient solution concentrations and LED lights, other studies have demonstrated how differing LED light ratios affect the uptake of mineral nutrients in leaf tissues. For example, Gerovac et al. indicated that LED light quality; ratio of red, green, far-red, blue; and LED light intensity had significant effects on macronutrient concentrations in Brassica microgreens. ${ }^{23}$ Previous research has also indicated sprouting broccoli shoot tissue macronutrients were significantly affected when grown under red and blue LED or five day preharvest blue LED light treatments. ${ }^{11}$ Metallo et al. found similar results with LED and white light and duration treatments for $\mathrm{K}$ concentrations in kale plants. ${ }^{24}$ Data indicated that $95 \%$ red/5\% blue at the 37-day treatments increased $\mathrm{K}$ concentrations to $4.87 \%$ compared to $3.61 \%$ in the white light treatment. In the current study, the interaction of light and fertility had a profound effect on the uptake of macronutrients in kale shoot tissue. Another study demonstrated that LED light treatment affect mineral nutrients such as $\mathrm{Ca}, \mathrm{K}, \mathrm{Mg}, \mathrm{P}$, and $\mathrm{S}$ in microgreen production. ${ }^{10}$ Similar results were discovered in the current study that indicated increases in mineral nutrients under LED lights compared to fluorescent/incandescent. Thus, LED light quality and an adequate fertility program can lead to a significant impact on increasing macronutrient uptake and concentrations in plant tissues, increasing the quality and nutritional content in edible kale tissue. In the current study, the results indicate that the biomass dilution effect is not a factor when increasing the nutrient solution concentrations under LED light quality conditions verses fluorescent/incandescent light, with adequate light intensities. Under this study and previous studies, the light intensities for growing 
leafy greens such as kale, have been approximately 250 to $350 \mu$ mols $\cdot \mathrm{m}^{2} \cdot \mathrm{sec}^{-1}$, indicating that within this light intensity range, plants given the correct LED light quality and increased fertility can have elevated concentrations of mineral nutrients.

There were less effects of the interaction of light and fertility on micronutrient concentrations in kale shoot tissue. Previous research indicated that the interaction of light quality and intensity decreased concentrations of $\mathrm{B}, \mathrm{Fe}$, and $\mathrm{Zn}$ in kohlrabi (B. oleracea var gongylodes), mizuna (B. rapa var japonica), and mustard [B. juncea (L.) Czern. 'Garnet Giant']. ${ }^{23}$ These results indicate that decreases in micronutrient concentrations may have been caused by increases in biomass under increased light intensity and pinpointed light quality giving a biomass dilution effect under these conditions.

LED light research on leafy greens has indicated that light ratios can be manipulated to impact mineral nutrient uptake and stimulate secondary metabolic pathways associated with nutritional quality factors. Several previous studies within our collaborative research efforts demonstrate the ability to increase secondary metabolic pathways and mineral nutrient uptake associated with nutritional quality factors. ${ }^{10,11,15,24}$ However, the current research study is the first to examine how novel LED light ratios and differing fertilizer regimes affect mineral nutrients uptake into plant root and shoot tissues. By manipulating light ratios and mineral nutrient concentrations, it is proven that plants can be manipulated with novel LED light ratios coupled with lower mineral nutrients for a more sustainable approach to plant growth.

should discuss the results and how they can be interpreted in perspective of previous studies and of the working hypotheses. The findings and their implications should be discussed in the broadest context possible. Future research directions may also be highlighted.

\section{Materials and Methods}

\section{Chinese Kale Culture and Harvest.}

'Green Lance' Chinese kale (Johnny's Selected Seeds, Winslow, ME, USA) were seeded into growing cubes (Oasis ${ }^{\circledast}$ Hortcubes $^{\circledR}$, Smithers-Oasis North America, Kent, OH, USA) and grown in controlled environment chambers (Model E15; Conviron, Winnipeg, Manitoba, Canada) at the University of Tennessee, Knoxville, TN. Seeds were cultured at an air temperature of $23{ }^{\circ} \mathrm{C}$ with a 16-h photoperiod using a light intensity of $250 \mu \mathrm{mols} / \mathrm{m}^{2} / \mathrm{sec}$ from fluorescent and incandescent bulbs. Five days after germination, seedlings were fertilized with a complete nutrient solution [elemental concentrations were (mg/L): N (52.5), P (7.7), K (58.7), Ca (40.1), Mg (12.3), S (16), Fe (0.25), $\mathrm{B}(0.12), \mathrm{Mo}(0.003), \mathrm{Cu}(0.005), \mathrm{Mn}(0.12)$, and $\mathrm{Zn}(0.012)]$. After 15 days, seedlings were transferred to $10 \mathrm{~L}$ plastic containers (Rubbermaid Inc., Wooster, OH, USA). Six plants were placed into $2 \mathrm{~cm}$ round holes set at $10.6 \mathrm{~cm} \times 9.5 \mathrm{~cm}$ spacing on each container lid to constitute an experimental unit. The plants were grown in $9 \mathrm{~L}$ of a modified nutrient solution..$^{13}$ The $1 / 4$ Hoagland's nutrient fertility treatment (solution \#2) elemental concentrations were (mg/L): $\mathrm{N}(52.5), \mathrm{P}(7.7), \mathrm{K}(58.7), \mathrm{Ca}(40.1), \mathrm{Mg}$ (12.3), S (16), Fe (0.25), B (0.12), Mo (0.003), Cu (0.005), Mn (0.12), and Zn (0.012). The 1/2 Hoagland's nutrient fertility treatment elemental concentrations were (mg/L): N (105.0), P (15.5), K (117.3), Ca (80.2), Mg (24.6), S (32.0), Fe (0.5), B (0.25), Mo (0.005), Cu (0.01), Mn (0.25), and Zn (0.025). The nutrient solutions were aerated with standard aquarium air pumps connected to air stones via plastic tubing.

Kale plants were grown under four different light treatments which consisted of: 1) fluorescent/incandescent light; 2) $10 \%$ blue ( $447 \pm 5 \mathrm{~nm}$, full width half maximum (FWHM) $=20 \mathrm{~nm}$ ) / 90\% red $(627 \pm 5 \mathrm{~nm}, \mathrm{FWHM}=20 \mathrm{~nm})$; 3) $20 \%$ blue / 80\% red; 4$) 40 \%$ blue / $60 \%$ red. A spectroradiometer (model SPEC-UV/PAR; Apogee Instruments, Logan, UT) was used to adjust and maintain a light intensity of $250 \pm 10 \mu \mathrm{mols} / \mathrm{m}^{2} / \mathrm{sec}$ at the center of each LED panel and the fluorescent/incandescent light treatment at canopy height. The fluorescent/incandescent light treatment was composed of cool-white fluorescent bulbs $(160 \mathrm{~W})$ and incandescent bulbs $(60 \mathrm{~W})$ and measured $15.3 \%$ blue $(400-500 \mathrm{~nm})$ and $26.4 \%$ red $(600-700 \mathrm{~nm})$ of total irradiance. The total irradiance of $250 \mu \mathrm{mols} / \mathrm{m}^{2} / \mathrm{sec}$ resulted in a total energy output of $52.3,49.4,51.3$ and $55.1 \mathrm{~W} / \mathrm{m}^{2}$ for the light treatment of fluorescent/incandescent, $10 \%$ blue / $90 \%$ red LEDs, $20 \%$ blue / $80 \%$ red LEDs, 
and $40 \%$ blue / $60 \%$ red LEDs, respectively. Treatments provided a red/blue light ratio of 1.7 for fluorescent/incandescent, 9 for $10 \%$ blue / $90 \%$ red, 4 for $20 \%$ blue / $80 \%$ red, and 1.5 for $40 \%$ blue / $60 \%$ red light treatments. Kale plants were harvested from each container at 30 days after seeding from all treatments. Plants were weighed for biomass accumulation and stored at $-80{ }^{\circ} \mathrm{C}$ prior to tissue pigment analyses.

Chinese Kale Tissue Mineral Element Analysis.

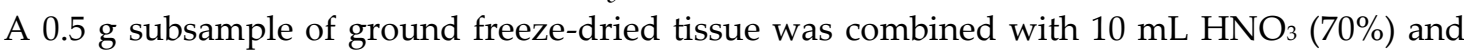
sealed in a closed vessel microwave digestion system (ETHOS series; Milestone, Shelton, CT, USA). Digestion procedures followed those for organically based matrices. ${ }^{14}$ Digestions were diluted with $2 \% \mathrm{HNO}_{3} / 0.5 \% \mathrm{HCl}(\mathrm{v} / \mathrm{v})$, and elemental measurements were made using an Agilent $7500 \mathrm{ce}$ ICP-MS system (Agilent Technologies, Santa Clara, CA, USA). The ICP-MS system was equipped with an octapole collision/reaction cell, Agilent 7500 ICP-MS ChemStation software, a micromist nebulizer, a water-cooled quartz spray chamber, and a CETAC (ASX-510; CETAC, Omaha, NE, USA) autosampler. The instrument was optimized daily in terms of sensitivity ( $\mathrm{Li}, \mathrm{Y}, \mathrm{Tl}$ ), level of oxide (Ce), and doubly charged ion (Ce) using a tuning solution containing $10 \mu \mathrm{g} / \mathrm{L}$ of $\mathrm{Li}, \mathrm{Y}, \mathrm{Tl}, \mathrm{Ce}$, and $\mathrm{Co}$ in a $2 \% \mathrm{HNO}_{3} / 0.5 \% \mathrm{HCl}(\mathrm{v} / \mathrm{v})$ matrix. Mineral elements were expressed on a DM basis and calculated as concentration $(\mathrm{mg} / \mathrm{g} ; \mu \mathrm{g} / \mathrm{g})$.

\section{Statistical Analyses.}

The experimental design was a randomized complete block in a two (fertility treatment) $x$ four (light treatment) factorial arrangement. The study was repeated three times. Data were analyzed using PROC GLM procedure of SAS (version 9.4; SAS Institute, Cary, NC, USA). Differences among light and fertility treatments means were determined by least significant difference $\left(\mathrm{LSD}_{\alpha=0.05}\right)$. Treatment by experimental run interactions were not detected, therefore data from each experimental repeat was combined and analyzed together.

Funding: This project was funded in part by USDA-NIFA-SBIR Project 2012-33610-19526. Any opinions, findings, and conclusions or recommendations expressed in this publication are those of the author(s) and do not necessarily reflect the view of the National Institute of Food and Agriculture (NIFA), the U.S. Department of Agriculture (USDA), or Orbital Technologies Corporation.

Conflicts of Interest: The authors declare no competing financial interests. The research was conducted at the University of Tennessee. Data analysis and writing of manuscript was conducted at Mississippi State University and the University of Florida.

\section{References}

1. Engels, C.; Kirkby, E.; White, P. Mineral nutrition, yield and source-sink relationships. In Marschner's Mineral Nutrition of higher Plants, $3^{\text {rd }}$ ed.; Marschner, P., Ed.; Academic Press, London, UK, 2012.

2. Römheld, V. Diagnosis of deficiency and toxicity of nutrients. In Marschner's Mineral Nutrition of higher Plants, $3^{\text {rd }}$ ed.; Marschner, P., Ed.; Academic Press, London, UK, 2012.

3. McCree, K. J. Test of current definitions of photosynthetically active radiation against leaf photosynthesis data. Agricultural Meteorology 1972, 10, 443-453.

4. Zuber, H. Structure of light-harvesting antenna complexes of photosynthetic bacteria, cyanobacteria and red algae. Trends Biochemical Sci. 1986, 11, 414-419.

5. Demmig-Adams, B.; Adams, III, W. W. The role of xanthophyll cycle carotenoids in the protection of photosynthesis. Trends Plant Sci. 1996, 1, 21-26.

6. Mills, H. A.; Jones, J. B. Jr. Factors affecting plant composition. In Plant Analysis Handbook II; MicroMacro Publishing, Inc.: Athens, GA, USA, 1996. 
7. Glass, A. D. M. Environmental influences on ion absorption. In Plant Nutrition: An Introduction to Current Concepts; Jones and Bartlett Publishers, Inc.: Boston, MA, USA, 1989.

8. Barber, S. A. Potassium. In Soil Nutrient Bioavailability: A Mechanistic Approach; Wiley \& Sons, Inc.: New York, NY, USA, 1995.

9. Zhao, X.; Wang, Y. L.; Qiao, X. R.; Wang, J.; Wang, L. D.; Xu, C. S.; Zhang, X. Phototropins function in high-intensity blue light induced hypocotyl phototropism in Arabidopsis by altering cytosolic calcium. Plant Physiol. 2013, 162, 1539-1551.

10. Kopsell, D. A.; Sams, C. E.; Barickman, T. C.; Morrow, R. C. Sprouting broccoli accumulate higher concentrations of nutritionally important metabolites under narrow band light-emitting diode lighting. J. Am. Soc. Hort. Sci. 2014, 139, 469-477.

11. Kopsell, D. A.; Sams, C. E. Increases in shoot tissue pigments, glucosinolates, and mineral elements in sprouting broccoli after exposure to short-duration blue light from light-emitting diodes. J. Am. Soc. Hort. Sci. 2013, 138, 31-37.

12. Baligar, V. C.; Fageria, N. K.; Paiva, A. Q.; Silveira, A.; Pomella, A. W. V.; Machado, R. C. R. Light intensity effects on growth and micronutrient uptake by tropical legume cover crops. J. Plant Nutr. 2006, 29, 1959-1974.

13. Hoagland, D. R.; Arnon, D. I. The water culture method for growing plants without soil. Calif. Agric. Expt. Sta. Circ. 1950, 347, 1-32.

14. Barickman, T. C.; Kopsell, D. A.; Sams, C. E. Selenium influences glucosinolate and isothiocyanates and increases sulfur uptake in Arabidopsis thaliana and rapid-cycling Brassica oleracea. J. Agri. Food Chem. 2013, 61, 202-209.

15. Kopsell, D. A.; Sams, C. E.; Morrow, R. C. Interaction of light quality and fertility on biomass, shoot pigmentation and xanthophyll cycle flux in Chinese kale. J. Sci. Food Agric. 2017, 97, 911-917.

16. Chen, X.; Yang, Q.; Song, W.; Want, L.; Gou, W.; Xue, X. Growth and nutritional properties of lettuce affected by different alternating intervals of red and blue LED irradiation. Sci. Hort. 2013, 223, 44-52.

17. Jones-Baumgardt, C.; Llewellyn, D.; Ying, Q.; Zheng, Y. Intensity of sole-source light-emitting diodes affect growth, yield, and quality of Brassicaceae microgreens. HortScience 2019, 54, 1168-1174.

18. Taulavuori, K.; Pyysalo, A.; Taulavuori, E.; Julkunen-Tiitto, R. Response of phenolic acid and flavonoid synthesis to blue and blue-violet light depends on plant species. Environ. Exp. Bot. 2018, 150, 183-187.

19. Yan, Z.; He, D.; Niu, G.; Zhai, H. Evaluation of growth and quality of hydroponic lettuce at harvest as affected by the light intensity, photoperiod and light quality at seedling stage. Sci. Hort. 2019, 248, 138-144.

20. Samuloiene, G.; Urbonaviciute, A.; Duchovskis, P.; Bliznikas, Z.; Vitta, P.; Zukauskas, A. Decrease in nitrate concentrations in leafy vegetables under a solid-state illuminator. HortScience 2009, 44, 1857-1860.

21. Liu, H.; Fu, Y.; Yu, J.; Liu, H. Accumulation and primary metabolism of nitrate in lettuce (Lactuca sativa L. var. Youmaicai) grown under three different light sources. Comm. Soil Sci. Plant Anal. 2016, 47, 1994-2002.

22. Bian, Z.; Cheng, R.; Wang, Y.; Yang, Q.; Lu, C. Effect of green light on nitrate reduction and edible quality of hydroponically grown lettuce (Lactuca sativa L.) under short-term continuous light from red and blue light-emitting diodes. Environ. Exp. Bot. 2018, 153, 63-71.

23. Gerovac, J. R.; Craver, J. K.; Boldt, J. K.; Lopez, R. C. Light intensity and quality from sole-source light-emitting diodes impact growth, morphology, and nutrient content of Brassica microgreens. HortScience 2016, 51, 497-503.

24. Metallo, R. M.; Kopsell, D. A.; Sams, C.E.; Bumgarner, N.R. Influence of blue/red vs. white LED light treatments on biomass, shoot morphology, and quality parameters of hydroponically grown kale. Sci. Hort. 2018, 235, 189-197. 